\title{
The pregnant man: race, difference and subjectivity in Alan Paton's Kalahariwriting
}

\author{
Hermann Wittenberg
}

\section{Introduction}

In South African imaginative writing and scholarly research, there is currently an extensive and wide-ranging interest in the 'Bushman', either as a tragic figure of colonial history, as a contested site of misrepresentation, or even as an exemplary model of environmental consciousness. Writing and research about 'Bushmen' has not only become pervasive in the academy, but also a site of controversy and theoretical contestation. It is in this context that this paper investigates the meaning and significance of 'Bushmen' for Alan Paton, one of South Africa's most well-known writers. Paton's writing is not usually associated with 'Bushman' studies, yet this article shows that the 'Bushman' became a highly charged and ambivalent figure in his imagination. Paton's problematic ideas are contextualised more carefully by looking at the broader context of South African letters. The article initially analyses Paton's representation of 'Bushmen' in his Lost City of the Kalahari travel narrative (1956, published in 2005. Pietermaritzburg: KZN Press), and also discusses unpublished archival photographs. A study of the figure of the 'Bushman' throughout the entire corpus of his writing, ranging from early journalism to late autobiography, allows us to trace the shift of his views, enabling us to reflect not only on Paton's thinking about racial otherness, but also gauge the extent to which his encounter with the Kalahari Bushmen destabilised his sense of self, finally also preventing the publication of the travelogue.

\section{I}

In contemporary literary and cultural studies there is a resurgence of interest in travel writing. No longer tainted with the whiff of the Victorian age and exclusively associated with the era of Western imperial expansion, travel narratives - and theories of travel writing - increasingly reflect on the various spatial and temporal displacements of twentieth century modernity, as encapsulated in a range of experiences such as exile, homelessness and nomadism. But despite the usefulness of travel writing as a form of text to interrogate diasporic identities, postcolonial criticism has generally been occupied with critiquing the genre's 'historical taintedness' (Kaplan 1999, 3). The travelogues of colonial explorers and the quest narratives of imperial writers such as Rider Haggard, Buchan and Kipling have thus long been the fertile ground for a large volume of postcolonial criticism (see for example work by Mary Louise Pratt, Anne McClintock, David Spurr, Sara Mills). In a wide range of studies that have interrogated 
the travel writing of empire, the travel writers' representations of otherness have been critiqued as a textual form of colonial incursion and violence.

Commenting on this trend in postcolonial criticism, Steve Clark has argued against the reduction of 'cross-cultural encounters to simple relations of dominance and subordination', claiming that 'postcolonial criticism has favoured the textual model of imperialism as a malign system constituted by diffuse and pervasive systems of power' (1999, 3). Instead of exclusively focusing on colonial power relationships between Westerners and the exotic other (as much postcolonial analysis has done), travel writing also allows insight into the complex narrative stagings of the mobile self, where identity is literally no longer fixed, and where there is a intricate layering of subjectivities. The significance of travel narratives is thus less connected to their representational veracity (the truth they may or may not speak of distant places and different people), but what they reveal about the complex workings of subjectivity in respect of their own authorship.

In looking at the problematic figure of the Bushman ${ }^{1}$ in Alan Paton's 1956 Kalahari travel narrative, this article will be therefore be taking a more cautious approach than that of a conventional postcolonial analysis. Reading Paton's descriptions of Bushmen through a straightforward postcolonial lens could easily lead to a reduction of his writing to yet another instance of colonial othering and racism, a problematic diagnosis that would also be significantly at odds with the dominant public image of Paton's liberalism, as exemplified by his famous novel, Cry, the Beloved Country (1948), and a life-long career of opposition to institutionalised racism and oppression. Instead, Paton's ideas will be contextualised more carefully by looking at the broader context of South African letters, as well as at his earlier writing on the subject. This investigation, I hope, will allow us to reflect not only on Paton's thinking about racial otherness, but will also allow us to gauge the extent to which his encounter with the Kalahari Bushmen produced a destabilising and profound form of ontological shock that has left its textual marks and finally also prevented the publication of Lost City of the Kalahari.

The facts of Paton's Kalahari exploit are well known enough since his narrative was published by UKZN Press in 2005, and I explored some of the problems around the text in my 'Introduction', suggesting that Paton suppressed the story after writing it, partly out of embarrassment of being swindled by Sailor Ibbetson (the quixotic brains behind the venture), but also because of a dramatic shift in public thinking around Bushmen. Paton's narrative tells the story of the Natal Kalahari Expedition that set out in 1956 with the objective to find the ruins of an ancient mythical lost city that was supposed to be located near the Aha Mountains in the remote north-west region of present-day Botswana. As Paton recounts in the narrative, he joined the adventure on a whim in the role of 'scribe and bottle-washer' $(2005,20)$, and spent a month in the desert travelling on the back of an old, decrepit Austin truck that broke down continually. Despite not finding anything of archaeological significance, Paton seems to have enjoyed the experience of roughing it in the bush, far removed from the troubling political tensions in South Africa in which he, as Liberal Party chairperson, had become increasingly embroiled. On his return Paton then wrote a narrative of the experience that not only satirised the incompetence and amateurism of the quest with self-deprecating humour, 
but also contained superb passages of evocative landscape description, and - the subject of this article - troubling ethnographic exposition.

\section{1}

What are then the problems with Paton's Bushmen? Paton encounters 'his' first Bushmen not far from Ghanzi and is disappointed (as all travellers have always been) that they are not 'pure' and 'wild' since they obviously pose for photographs. A conventional ethnographic description follows that details size, clothing and physical characteristics:

The men were just over five feet in height, the women a little shorter. Some appeared of tremendous age, but perhaps they were not really old, for a nursing mother with a babe looked at least 60 . The men wore nothing but a girdle, from which ran, from front to back, a black piece of cloth under the crotch, like a pair of swimming trunks simplified away. The women wore little more; what clothes they wore, some of skin, and some of manufactured cloth, were also black ... Some bushwomen exhibit steatopygia in small or great degree, that is the accumulation of fat on the buttocks, which is said to be Nature's provision for the unborn child in times of hunger. Neither men nor women are beautiful, their hollow backs, protuberant bellies and spindly legs prevent it. $(2005,41)$

The familiar stock elements of colonial Bushman ethnography are all present in stereotypical plenitude, and the descriptive details focus on aberrancy, lack and deficiency which serve to depict the radical otherness of Bushmen.

The moment of cross-cultural encounter, such as the one described above, is of course a set-piece of colonial and modernist travel writing. As Richard Kerridge has argued (1999, 164-182), the contact between the Western traveller and the native cannot remain suspended in the stasis of a gaze of mutual misrecognition. The phases of confrontation, climax and recoil in the face of radical otherness and difference generally give way to a retreat into detachment, a detachment that can take the form of either elaborate hyper-attenuated ethnographic description, an imaginary eroticized fantasy of desired intimacy, or, conversely, disgust and recoil. If we follow Kerridge's model of cross-cultural encounter, Paton's reaction to the Ghanzi Bushmen is marked precisely by such detachment, here initially taking the form of a retreat into the 'safe', wellelaborated and supposedly objective discourse of ethnography - a discourse which, it is important to note, was not as yet politically incorrect in the 1950 .

Kerridge's other form of detachment in the face of cross-cultural encounter is disgust and recoil. In Paton's narrative it is ultimately the issue of dirt that leads to a deep 'revulsion':

The dirt of the Kalahari seems to become one with the skin, even on the head. It was my first acquaintance with such primitive human life and though it was there before my eyes, I found it hardly credible. Had I stayed with them, no doubt I would have begun to have an affection for them; but as it was I experienced a revulsion, perhaps not so much from them as from their nasty and brutish life, so that I did not really care to stand and observe them. Or it may have been that their skin was dry, dirty and rough, which is a condition I cannot endure for myself. $(2005,43)$ 
Although a more nuanced reading is possible here (he distinguishes between his disgust with the way of life and of the Bushmen per se), Paton is clearly troubled and unsettled by his own reaction. The proliferation of the personal pronoun ' $\mathrm{I}$ ' in the passage reveals a mirrored turning back of the ethnographic gaze from the looked at object back to the subject itself, provoking an uneasy inward reflection on his own consciousness which is no longer sure of its own senses and thoughts. The destabilisation of self even leads momentarily to a dangerous collapse of difference between self and other when the dirt on 'their skin' is felt to be 'a condition I cannot endure for myself'. Paton's use of the subjunctive and a complex structure of subordinate clauses indicate this uncertainty and self-doubt on a textual level.

Before tracing the genealogy and context of Paton's reaction to the Ghanzi Bushmen in more detail, it is also worth looking at the visual record of the expedition. Even though it soon lapsed into obscurity, one of the remarkable aspects of the Natal Kalahari Expedition was its insistence on record-keeping. Not only did the expeditionaries enlist a world-famous novelist as their 'scribe', but also numerous forms of visual documentation, including filming and mapping, accompanied their progress: Terrence Spencer, a Life magazine photographer flew in from Britain as the official photographer, and several other amateur photographers in the party documented their travels, among them Keith Walker, a Michaelhouse College Physics teacher who also took responsibility for navigation. Walker's images have only recently come to light, after the publication of Paton's travelogue. Among the hundreds of pictures showing the landscape and people of the Kalahari, as well as the expeditionaries themselves, there is only one surviving photograph that shows us both Paton and the Kalahari Bushmen in the same frame (see opposite). Unlike Spencer's superbly lighted and composed images, Walker's photograph is more of an amateur tourist snap-shot. In Walker's scrapbook it is captioned as 'Pregnant Man', clearly a reference to the body shape of the image's main subject, but what is more interesting here than matters of anatomy is what it shows about Paton. Sitting on the oil drum with his arms crossed, eating an orange, his back is turned to the stranger in the foreground; his body has averted itself. Paton's reluctant backward glance, perhaps prompted by a call from the photographer, does not quite meet the camera, even less so the man in the foreground. The other expedition member in the photograph, Terrence Spence, is by contrast more engaged with the scene in front of him. It is of course easy to read too much into a single photograph which is only the record of a particular, transitory moment frozen in time, but it is nevertheless striking how much Paton's lack of engagement and indeed his aversion - as visible in this singular moment - corresponds to the textual record of this encounter, as cited above. In contrast to Paton's body language and the words that he would soon afterwards write into the notebook visibly tucked under his elbow, is the fact that there are hundreds of other photographs of Bushman subjects in Spencer's and Walker's albums, showing that the Bushmen clearly exerted a special fascination for the explorers. Unlike Paton, who could 'not really care to stand and observe them', the others in the party regarded the Bushmen as ethnographic objects to be looked at and photographed. 


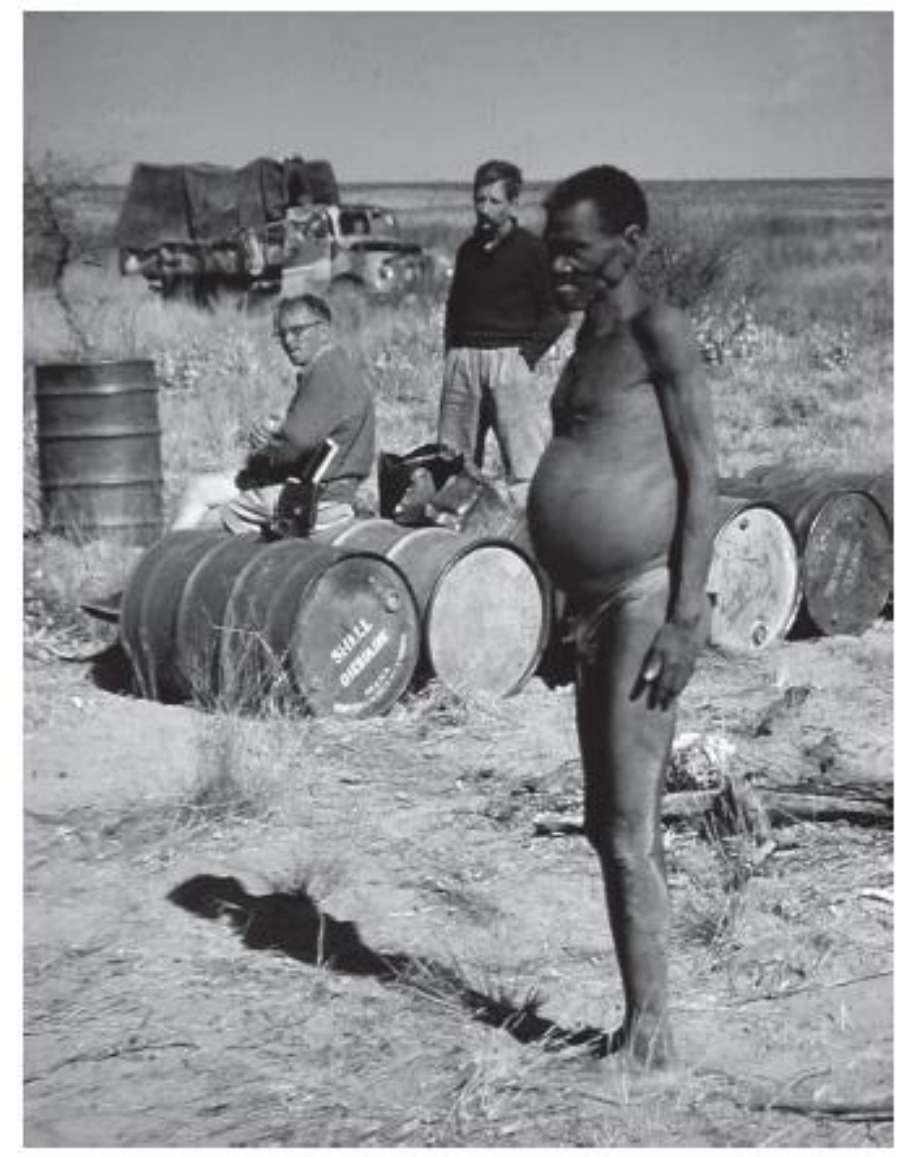

\section{1}

But overall, Paton's Hobbesian views suggest that this encounter on the Ghanzi roadside was coloured by a long tradition in South African letters that regarded Bushmen less as people and more as animals. A.E. Voss has traced the changing image of the Bushman in two centuries of South African English writing: 'The dominant view of the Bushman from about 1850 until the 1920 s is of a barely human, duplicitous, cruel savage. Late in the nineteenth century the seeds are sown of the neo-Romantic, modern image of the Bushman - kind, noble, indomitable, independent, infinitely adaptable to Nature because infinitely wise in her ways.' $(1987,26)$

The mid-nineteenth century views on Bushmen were in sharp contrast to the earlier poems of Thomas Pringle, in which his 'bushboy' companion 'afar in the desert' is indebted to the tradition of the noble savage. ${ }^{2}$ The discourse of the latter nineteenth century saw the rise of an increasingly aggressive disparagement of Bushmen. David Maughan-Brown similarly detects a waning of the Noble Savage myth, and by the time of the 1847 Bushman exhibit in the Egyptian Hall in London, The Times could write: 'In appearance they are little above the monkey tribe, and scarcely better than mere brutes on the field . . . They are sullen, silent and savage - mere animals in propensity, and worse than animals in appearance' (quoted in Maughan-Brown 1987, 58). Such attitudes were shared by Charles Dickens, who saw the exhibition and declared that he 'abhors, detests, abominates and abjures' the 'horrid little leader . . . in his festering bundle of hides, with his filth and his antipathy to water, and his straddled legs, and his odious eyes shaded by his brutal hand' (Maughan-Brown, 1987, 59). Such attitudes were also held by missionaries in Southern Africa such as Livingstone, who, drawing on 
Darwin's Origin of the Species (1859), believed that 'the Bushmen of the Desert are perhaps the most degraded specimens of the human family' (quoted in Voss, 1987, 26). Even as late as 1924, in 'The Karroo', the poet Francis Carey Slater could describe Bushmen as 'scattered and wandering pygmies, hideous, filthy, and squat' (quoted in Voss, 1987, 27). Paton's views, as revealed in the Kalahari narrative, would place him in this tradition, making him one of the most belated exponents of the 'nasty and brutish' character of the Bushmen.

But by the end of the nineteenth century the eradication of Bushmen as a threat to farming, coupled with a diminishing importance of agriculture in an increasingly modern and industrialising South Africa, had brought about material conditions for a change in attitudes. With the virtual absence of real Bushmen on the land, a nostalgic myth could develop that would value them as representatives of a vanishing species of humanity. The threat of Bushman extinction allowed a more sympathetic and benign outlook, which was increasingly concerned with preserving the remnants of an ancient culture. One of the earliest exponents of such attitudes was W. H. Bleek's and Lucy Lloyd's celebrated linguistic and ethnographic research of /Xam or Cape Bushman culture, which already started in the 1870s. Even Farini, who earned money out of Bushman exhibitions, already believed that 'the Bushmen and other local tribes are too little known, and if properly studied in this, their free homes, before they become first contaminated and then exterminated by civilisation, much important ethnographic information will be obtained' $(1886,53)$.

The increasingly sympathetic view of Bushmen around the turn of the century was part of a wider conservationist movement that took interest preserving the vanishing wildlife and heritage of South Africa. The first South African nature and wildlife reserves were declared in the last decade of the nineteenth century. By regarding Bushmen as just another type of wildlife threatened with extinction, these conservationist discourses paradoxically however perpetuated the older colonial notions of animal-like Bushmen. Just as the wildlife of South Africa, the Bushmen also had to be preserved, whether in parks such as the Kalahari Gemsbok or, if not living, in the form of casts and museum displays such as the controversial dioramas in the South African Museum. Bushmen would be conserved, but only if they remained trapped in the ahistorical, natural world of fauna and flora. General J. C. Smuts's linkage of Bushmen and animals in 1937 is typical of this conservationist discourse: 'If they live in their traditional way, and kill game in the process, we will protect them. We will treat them as we treat the game. If they shoot with bow and arrow, and live in their primeval way, according to their traditional methods, we shall not disturb them' $(1951,53)$.

The implicit threat is that Bushmen are valued and protected only as long as remain in their 'primeval' world among the animals; culturally pure and isolated from the rest of humanity. Should they show any signs of acculturation or technological progress (such as using guns), this protection would turn to prosecution. In Smuts's view, the borders around this cultural and racial purity needed to be sharply policed in order to avoid 'problems'. Impure Bushman, or those who 'pose as Bushman' like 'half-breeds such as Griquas and Bastards' and shoot game with guns 'not to live but to gain' will be punished with the full force of the law $(1951,53)$. It is clear, then, that Bushmen can only be 
tolerated in modernity as primitives, remaining part of the natural world of wildlife and denied full accession to humanity. This is a discursive configuration which has changed comparatively little in the last hundred years, if we consider recent tourism marketing efforts. ${ }^{3}$ As Paul Landau's astute analysis of the shifts in the history of Bushman photography reveals, shooting with the camera replaced shooting with the gun, but the image of the Bushman remains trapped "in a discourse in which "natural" animals and people both were valued and thought worth preserving. Thenceforth bushmen stayed in a "natural" aspect for the Western imagination - a position maintained, against all odds, even today' $(1996,129)$.

By and large, Bushmen, as long as they remained 'natural' and uncontaminated by progress became not only objects of sympathy in the twentieth century, but could also be imagined as subjects with whom one could identify. The Bushman could even be coopted into the project of South African modernism and the avantgarde. As William Plomer would write in 1926, in Voorslag, he and the other 'Voorslagters' were 'like twentieth century Bushmen, [who] had left vivid paintings on the walls of that dark cave, the mind of the White South African' (quoted in Voss, 1987, 35). Voorslag, the rebellious literary magazine that saw its mission in bringing international modernism to the cultural backwaters of colonial South Africa, was founded by Plomer, Roy Campbell and Laurens van der Post. The Voorslag trio represent a progressive, radical tradition in South African literature from which Paton's writing was quite distinct, but also, as we can see, curiously intertwined. 4

lV

Paton's and Van der Post's paths must have literally crossed in the Kalahari, and their respective visits to the Aha Mountains and Tsodilo Hills were less than a year apart. 5 Despite this temporal and spatial proximity, their respective travel narratives are worlds removed. These differences emerge out of profoundly divergent conceptions of the Bushman people of the Kalahari. In Paton's Kalahari narrative, Bushmen are largely absent, defined by lack and squalor, and he has initially difficulty imagining them as human. Van der Post's Lost World of the Kalahari, on the other hand, is a remarkably passionate and sustained homage of the Bushmen, who 'moved in the glare and glitter of Africa with a flame-like flicker of gold' $(1988,10)$. Their language, often an object of colonial disparagement, is transmuted into sheer poetry: 'the click of the complex consonants flashes on his tongue as he utters them as the sparkle of sun on a burst of flower from our sombre mountain gorse' $(1988,11)$. Their skin, for Paton 'dark', 'rough' and 'dirty', becomes, in van der Post's enchanted eyes, 'a lovely Provençal apricot yellow' (1988, 10). Van der Post's evocative language and Mediterranean imagery create a powerful mythic image of the Bushmen living in an African Eden as first people. As a natural human being, the Bushman 'contained, and was contained, deeply within the symmetry of the land' (1988:19) and possessed an authenticity and purity of soul that had been lost to modern man. The allure of the Bushman for van der Post lay precisely in the promise of a recovery of an elemental, more deeply authentic self: 'With our twentieth century selves we have forgotten the importance of being truly and openly primitive. We need primitive nature, the First Man in ourselves, it seems, as the lungs need air and the body food and water' $(1988,122)$. 
Contrary to Paton, the term 'primitive' is here positively charged. Such a valorisation of primitivity is indeed a characteristic commonplace for much European modernist art and writing, and compared to van der Post's passionate homage to the Kalahari Bushmen, Paton's Kalahari narrative, reveals a datedness which must subsequently have been become painfully obvious to Paton. Van der Post's powerful nostalgia for the 'lovely Provençal apricot yellow' Bushmen, and his paintings that 'burn within the aubergine shadows of the cave and overhang of cliff and krans' $(1988,25)$, completely overshadowed Paton's travelogue. Indeed, van der Post's interpretation of Bushman culture made Lost World an authoritative landmark text that almost single-handedly shifted public opinion. Edwin Wilmsen, one of the most influential scholars of the Kalahari Bushmen, describes this shift as follows: 'Times had changed dramatically in a decade; the Bushman who few wanted to see in 1950 was, by 1960, the hottest show on the road, with administration, academia, and the media vying for production rights' $(1995,222)$. In a context where the public image of Bushmen was largely shaped by Lost World, and Van der Post's subsequent Kalahari writing, Paton would have found it difficult, if not impossible, to publish his own text. Written on the cusp of a widespread popular enthusiasm for Bushmen, the Kalahari episode became a story which Paton would try to erase and forget.

But it is also important to recognize that Paton's views on Bushmen were in many ways more grounded and realist than the idealist myth-making in van der Post's writing. As Patrick Holland and Graham Huggan have recently pointed out, there are contradictions between Van der Post's 'portrayal of the Bushmen as on the one hand as "survivor-victims of European imperialism" and, on the other, "primal beings virtually untouched by history" (2004, 148). In Van der Post, search for universal truths the historical is evaded, and the Bushman becomes a figure in the service of modernist nostalgia for authenticity. 'The twin prongs of the genre of travel writing', as Holland and Huggan claim, are 'amateurism and anachronism' (2004, 148). If Van der Post's ahistorical myth-making is fatally flawed on both counts, Paton's narrative is more exemplary of the former flaw, as he himself cheerfully admitted.

\section{$\mathbf{V}$}

In order to further contextualise Paton's views about the Kalahari Bushmen, it is important to trace the genealogy of his treatment of Bushmen in his other writing. In one of Paton's earliest reference to Bushmen, in a 1949 article dealing with South Africa's racial problems, he sketches the country's history and refers to the 'aboriginal inhabitants of the country, the not very aggressive Hottentots, and the much more aggressive but animallike Bushmen' $(1949,1)$. They could, however, not hinder the advance of Dutch settlers as the colony moved further into the interior and consequently 'fled into the mountains and caves, gradually to be exterminated for their depredations and their irreconcilability' $(1949,1)$. Coming only a year after the celebrated compassion and humanism of Cry, the Beloved Country, Paton's views place Bushmen firmly in the realm of the non-human. In keeping with standard attitudes of time, their demise is represented as an agentless event ${ }^{6}$ and the blame for their extermination is placed on their 'depredations' and 'irreconcilability'. 
In 1955 Paton wrote a high school text book on South Africa intended for the US market. The Land and People of South Africa takes its readers on a grand tour through the history and geography of the country with Paton in the role of a personal tour guide ('let us stop here and look', 'After twenty miles we will come to', 'You will notice that'). Here, Bushmen are again unfavourably regarded as more 'primitive people' $(1955,82)$ than the Hottentot, but their accomplishments in hunting and art are given recognition: they 'were great hunters with poisoned arrows, and they have left behind fascinating rock paintings in caves'(1955, 82). Paton's explanation of their extermination now identifies the 'white man' as the agent, but the narrative structure of the sentence presents the killing of Bushmen as a warranted consequence of raids and thieving: "With the coming of European civilisation, they withdrew farther and farther, into mountain fastnesses or into the desert. They raided the white men's cattle and possessions, and the white man in their turn pursued and killed them' $(1955,82)$. Paton's closing remarks on Bushmen leave them firmly anchored in the world of wildlife: 'Today there are very few left; they live in the Kalahari Desert, and are protected by the Government, in much the same way as the wild animals of the Kruger Park' $(1955,83)$.

The following year, Paton went on the Kalahari trip and encountered for the first time, we can assume, Bushmen. His consequent revulsion of 'primitive' Bushmen and their 'nasty and brutish' life is not out of line, as we have seen, from his pre-Kalahari writing that stresses the Bushman's proximity to animals. By the time however that Paton wrote the first part of his autobiography, Towards the Mountain (1980) almost twentyfive years later, his views on Bushmen appear radically revised. But even here, the passage opens with a troubling sentence that places South Africa's early 'inhabitants' in the same category as the 'wild animals': 'In the days before writing was known to South Africa, before there were historical records, the majority of the inhabitants were wild animals' (1980, 47). The passage that follows is however a generous assessment of Bushman culture:

This earthly paradise was lived in by several peoples of whom I shall name two. One were the San people (once called the Bushmen), people of small stature, magnificent hunters and trackers, superb marksmen with the bow and arrow. They knew all about the herbs and plants of the veld, as food, as medicine, and as the sources of some very virulent poisons with which they tipped their arrows. They worshipped the moon and ascribed supernatural or magical properties to certain creatures such as the praying mantis. But their immortal achievement was their rock painting, in which figured humans, animals, birds, and the pleasures of the chase. $(1980,47)$

Paton focuses on the culture and art of the Bushmen rather than their physical characteristics. But it is also important to note that this information postdates van der Post's. The fact that he even distances himself from the term 'Bushman' shows him not only in tune with popular opinion, but also aware of recent revisionist academic debates.

\section{V1}

What emerges out of a reading of the Kalahari travelogue and Paton's other early writing is that the figure of the Bushman is treated as quite distinct from that of the 'native'. In Paton's very early writing, the Bushman exists on the fringes of humanity, and is indeed a 
radical figure of racial difference and human otherness. Viewed through the critical postcolonial lens, the Bushman here emerges, unlike the black peoples of South Africa, as Paton's fully developed colonial other. But it is also evident that Paton's views need to be evaluated in the larger context of writing about Bushmen in South African letters, and moreover, that his views were fluid and subject to substantial modification over the course of time. In the case of the Kalahari encounter at Ghanzi, it is clear that Paton was obviously disturbed by the intensity of his own reactions, and it is this uneasy selfawareness of his own repudiated repulsion that needs to be taken into account when assessing his views. A more careful reassessment of the politics of race in Paton's thinking therefore needs to account of this complexity of subjectivity in the face of a crosscultural encounter quite unlike those he was familiar with in his native South Africa. Such a reassessment also needs to acknowledge the fact that Paton successfully kept his Kalahari story out of the public domain during his life time. We may not know whether this was one way of solving some of the contradictions posed by his Kalahari experience, but the very fact that he suppressed his Kalahari writings is possibly his last unspoken word on the matter, indicating perhaps that, finally, the story of the lost city was itself to be lost.

\section{Notes}

1. The term 'Bushman' is used reluctantly in this article, and the author is aware of its controversial nature and derogatory implications. Paton's text uses this term and the use of other terms in my commentary and analysis would be confusing and inconsistent. The use of alternate terms such as San is also not entirely unproblematic.

2. See also Pringle's poem 'Song of the Wild Bushman' in which the 'lord of the Desert Land' 'his den doth yet retain' in the face of colonial persecution.

3. See for instance Gordon et al. (1996).

4. Apart from the Kalahari connection between Paton and van der Post, some of the other links are more well known: Paton was a life-long admirer of Campbell's modernist verse and had made considerable progress on a biography of the poet before passing on the task to Peter Alexander. Alexander subsequently became Paton's biographer. Plomer had become Cry, the Beloved Country's first English editor when Plomer's publishing house bought the United Kingdom rights from Scribners. And Van der Post's Lost World begins with Roy Campbell's evocative incantation: 'Pass world!: I am the dreamer that remains; / The man clear cut against the last horizon.'

5. Van der Post's Kalahari travels began in September 1954, lasting until the spring of 1955. Paton arrived in the area at the end of June 1956. The Natal Kalahari Expedition were delighted to find Van der Post's name in the guest house register directly above theirs in Nokaneng.

6. See Nigel Penn's “Fated to Perish”. The Destruction of the Cape San' (1996). Penn's title quotes the South African historian Theal, who represented the Bushmen's history as an agent-less demise. Penn's research reveals a complex colonial history of commando campaigns to subdue, capture and exterminate the San. 


\section{References}

Clark, Steve. 1999. Introduction. In Travel Writing and Empire: Postcolonial Theory in Transit. ed. Steve Clark. London and New York: Zed Books.

Farini, G. A. 1886. A Recent Journey in the Kalahari. Royal Geographic Society VII: 437453. Giddings, Robert. ed. 1991. Literature and Imperialism. London: Macmillan.

Gordon, Rob; Ciraj Rassol and Leslie Witz. 1996. Fashioning the Bushman in Van Riebeek's Cape Town, 1952 and 1993. In Pippa Skotnes. ed. Miscast. Negotiating the Presence of the Bushmen. Cape Town: University of Cape Town Press.

Holland, Patrick and Graham Huggan. 2004. Varieties of Nostalgia in Contemporary Travel Writing. In Perspectives on Travel Writing. eds. Glenn Hooper and Tim Youngs, 139-166. Aldershot: Ashgate Publishing.

Kaplan, Caren. 1998. Questions of Travel. Durham: Duke University Press.

Landau, Paul. 1996. With Camera and Gun in Southern Africa. Inventing the Image of the Bushmen, c.1800 - 1935. In Miscast. Negotiating the Presence of the Bushmen. ed. Pippa Skotness. Cape Town: University of Cape Town Press.

Maughan Brown, David. 1983. The Noble Savage in Anglo Saxon Colonial Ideology. English in Africa 10 (2): 55-78.

McClintock, Anne. 1995. Imperial Leather. Race, Gender and Sexuality in the Colonial Context. New York: Routledge.

Paton, Alan. 1949. South Africa's Racial Problems of an intensity and complexity unknown to any other country. Alan Paton Centre: PC 1/8/88/12.

_ . 1950. Why I write. Alan Paton Centre: PC 1/8/1/1/17.

.1955. The Land and People of South Africa. Philadelphia and New York: Lippincott.

. 1980. Towards the Mountain. Harmondsworth: Penguin.

. [1948] 1998. Cry, the Beloved Country. Harmondsworth: Penguin.

. [1956] 2005. Lost City of the Kalahari. ed. H. Wittenberg. Pietermaritzburg: University of KwaZulu-Natal Press.

Penn, Nigel. 1996. Fated to Perish. The Destruction of the Cape San. In Miscast. Negotiating the Presence of the Bushmen. ed. Pippa Skotnes. Cape Town: University of Cape Town Press.

Pratt, Marie Louise. 1992. Imperial Eyes. London: Routledge.

Pringle, Thomas. 1970. Poems Illustrative of South Africa. ed. John Robert Wahl. Cape Town: Struik.

Kerridge, Richard 1999. Ecologies of Desire: Travel Writing and Nature Writing as Travelogue. In Travel Writing and Empire: Postcolonial Theory in Transit. ed. Steve Clark, 164-182. London and New York: Zed Books.

Smuts, Jan Christiaan. 1951. The Thoughts of General Smuts. Compiled by his Private Secretary (P. B. Blanckenberg). Cape Town: Juta.

Van der Post, Laurens. 1988. The Lost World of the Kalahari. London: Chatto \& Windus. Voss, A. E. 1987. The Image of the Bushman in South African English Writing of the Nineteenth and Twentieth Centuries. English in Africa 14 (1): 21-40.

Wilmsen, Edwin. 1995. Primitive Politics in Sanctified Landscapes: The Ethnographic Fictions of Laurens van der Post. Journal of Southern African Studies. 21 (2): 201223.

Wittenberg, Hermann. 2005. Introduction. In Lost City of the Kalahari. Alan Paton. Pietermaritzburg: University of KwaZulu-Natal Press. 